\title{
Influence of Fluoride Ions in Artificial Saliva Solution to Corrosion Behavior of Ti-6Al-4V and Ti-10Mo-4Zr Titanium Alloys
}

\author{
Joanna Locha*, Halina Krawiec ${ }^{\text {a }}$ \\ ${ }^{a}$ AGH University of Science and Technology, Faculty of Foundry Engineering, Reymonta 23, 30-059 Krakow, Poland \\ *e-mail: loch@agh.edu.pl
}

Received: 25 June 2018/Accepted: 12 October 2018/ Published online: 31 October 2018

This article is published with open access by AGH University of Science and Technology Press

\begin{abstract}
Titanium alloys used in medical applications (especially dentistry) are exposed to the actions of various compounds that appear periodically in the mouth. Fluorine compounds are dangerous for the surface of titanium alloys, because they generate a dissolution of the passive layer. In this way, they destroy the surface of dental implants and cause the absorption of metal ions into the human body.

The presented work was aimed to describe the effect of fluoride ions on the corrosive behavior of the commercial Ti-6Al-4V and new Ti-10Mo-4Zr alloys that can be used in stomatology. Electrochemical measurements such as open circuit potential (OCP), linear sweet voltamperometry (LSV) and impedance spectroscopy (EIS) were performed to get information on the corrosive behavior of titanium in artificial saliva solutions (MAS) with different concentrations of NaF. It has been revealed that a high concentration of fluoride ions enhance the current density in the anodic domain, especially for the Ti-10Mo-4Zr alloy. EIS measurements performed at a potential of $0.5 \mathrm{~V}$ vs. $\mathrm{AgCl}(3 \mathrm{M} \mathrm{KCl})$ show that the Ti-10Mo-4Zr alloy has a typical two-layer structure of its passive film. This passive film consists of the outer and inner layers, respectively. The resistance of the outer layer is significantly lower than the resistance of the inner layer.
\end{abstract}

\section{Keywords:}

titanium alloys, artificial saliva solution, fluoride ions, corrosion

\section{INTRODUCTION}

In recent years, research on titanium alloys in medical applications has become very popular. The research direction is focused on the search for new titanium alloys and determining their physicochemical properties. In orthopedics and dentistry, a very important aspect is the durability and functionality of endoprostheses. Titanium alloys are used for biomedical applications because they have suitable mechanical properties (as endoprothesis), good biocompatibility with tissues, and very good resistance to local corrosion. Currently, Ti-6Al-4V is a commonly used titanium alloy. Only after extended use of this titanium alloy did we realize that aluminum and vanadium can have adverse effects on the human body. Therefore, new titanium alloys have non-toxic elements [1-3]. Research on the corrosion resistance of the new titanium alloys is designed to isolate those alloys that will have similar corrosion resistance as do alloys with aluminum and vanadium. There are many publications describing alloys with the additions of niobium, tantalum, zirconium, and molybdenum under various conditions [4-14].
The determination of the influence of an electrolyte (which is a simulated physiological solution) is important in the corrosion tests. In vivo tests, salt solutions are often used: Ringer and Hank's solution, artificial saliva solutions, and phosphorate buffered saline (PBS) with various organic and inorganic chemicals. Saliva solution composition is variable throughout the day, which results from the variety of products consumed. There are also substances that occur periodically; e.g., citric acid, calcium carbonate, and others. The content of fluoride (which also acidifies the environment) is characteristic for the composition of artificial saliva. Fluoride is located in the mouth because it is a component of toothpaste and mouthwash. In the case of people with titanium implants, this is dangerous [4,15-18]. The too-long and frequent use of products containing $\mathrm{F}^{-}$fluoride ions may dissolve the passive layer of alloys by the presence of hydrofluoric acid and its derivative compounds [19-24].

In this paper, the influence of fluoride ions on the corrosive behavior of both titanium alloys (Ti-6Al-4V and Ti-10Mo-4Zr) in a Mayer artificial saliva solution (MAS) is presented. 


\section{EXPERIMENTAL}

\subsection{Samples and solution}

The Ti-6Al-4V commercial alloy and new biomedical Ti-10Mo-4Zr titanium alloy (Goodfellow) were used in this investigation. The titanium alloys were mechanically ground using abrasive papers (SiC) down to 4000 grit and polished using diamond pastes $(3$ and $1 \mu \mathrm{m})$. Finally the samples were polished using a $0.02 \mu \mathrm{m}$ non-crystallizing colloidal silica suspension. Between each step, the specimens were ultrasonically cleaned in ethanol. In order to reveal the microstructure, both Ti alloy specimens were etched in a Koll's solution $(5 \mathrm{ml} \mathrm{HNO}, 10 \mathrm{ml} \mathrm{HF}, 85 \mathrm{ml}$ $\mathrm{H}_{2} \mathrm{O}$ ) for 5 seconds and rinsed in distilled water and then in ethanol.

The electrochemical tests were performed in a Mayer artificial saliva solution (MAS). The chemical composition of the MAS is presented in Table 1. Experimental measurements were performed by adding sodium fluoride in the following different amounts to the MAS solution (Tab. 2).

Table 1

Chemical compound of Mayer artificial saliva solution (MAS) in $\mathrm{H}_{2} \mathrm{O} ; \mathrm{pH}=6.4$

\begin{tabular}{lcccccc}
\hline \multicolumn{7}{c}{$\begin{array}{c}\text { Chemical compound, } \\
\text { g// } \text { solution }\end{array}$} \\
\hline $\mathrm{NaCl}$ & $\mathrm{KCl}$ & $\mathrm{NaHCO}_{3}$ & $\mathrm{Na}_{2} \mathrm{HPO}_{4}$ & $\mathrm{KSCN}$ & $\mathrm{Na}_{2} \mathrm{~S} \cdot 9 \mathrm{H}_{2} \mathrm{O}$ & Urea \\
\hline 0.7 & 1.2 & 1.5 & 0.26 & 0.3 & 0.005 & 1.0 \\
\hline
\end{tabular}

Table 2

Artificial saliva solution (MAS) with added sodium fluoride

\begin{tabular}{ccc}
\hline $\begin{array}{c}\text { Indication of } \\
\text { solution }\end{array}$ & $\begin{array}{c}\text { Content of NaF, } \\
\text { g// } \text { solution }_{\text {m }}\end{array}$ & pH of solution \\
\hline MAS + $5 \mathrm{NaF}$ & $5.0 \mathrm{~g}(\sim 0.5 \%)$ & 6.2 \\
\hline $\mathrm{MAS}+25 \mathrm{NaF}$ & $25.0 \mathrm{~g}(\sim 2.5 \%)$ & 7.4 \\
\hline
\end{tabular}

\subsection{Experimental methodology}

Global electrochemical experiments were carried out at $37^{\circ} \mathrm{C}$ using a PGSTAT302 AUTOLAB potentiostat/galvanostat with an FRA (frequency response analyzer) module. The corrosion tests were performed in a classical electrochemical cell where the following electrodes were placed: a platinum grid was used as a counter electrode, the specimen of the Ti alloy was a working electrode, and $\mathrm{Ag} / \mathrm{AgCl}$ (a $3 \mathrm{M} \mathrm{KCl}$ solution) was a reference electrode. All measurements were made in MAS containing 5 and $25 \mathrm{~g} / \mathrm{l} \mathrm{NaF}$, respectively.

The evolution of the open circuit potential (OCP) was measured for $24 \mathrm{~h}$ in the MAS solution at $37^{\circ} \mathrm{C}$. The potentiodynamic polarization (LSV) curves were recorded for both Ti alloys in the MAS solution within a potential range of -1.0 to $+2.5 \mathrm{~V}$ (vs. $\mathrm{Ag} / \mathrm{AgCl}$ ). The LSV curves were performed at a potential scan rate of $1 \mathrm{mV} / \mathrm{s}$. Electrochemical impedance spectroscopy (EIS) diagrams were plotted within a frequency range of $100 \mathrm{kHz}$ to a few $\mathrm{mHz}$ (30 points) using a $20 \mathrm{mV}$ peak-to-peak sinusoidal potential difference. The experiments were performed after $1800 \mathrm{~s}$ of immersion at various applied potentials: in the anodic domain $(0.5 \mathrm{~V}$ vs. $\mathrm{Ag} / \mathrm{AgCl})$. The impedance spectra were fitted by means of an equivalent circuit using the Z-view software package.

\section{RESULTS AND DISCUSSION}

\subsection{Microstructure of titanium alloys}

Commercial titanium alloy Ti-6Al-4V is composed of two metallic phases (the $\alpha$ - and $\beta$-phases). The average grain size are around 5-10 $\mu \mathrm{m}$ in both phases. By contrast, the second alloy (Ti-10Mo-4Zr) is composed of one $\beta$ metallic phase. The grain size are roughly ten times larger than in the previous case - about $100 \mu \mathrm{m}$ (Fig. 1). A detailed description of the chemical composition of the phases is presented in [9].

a)

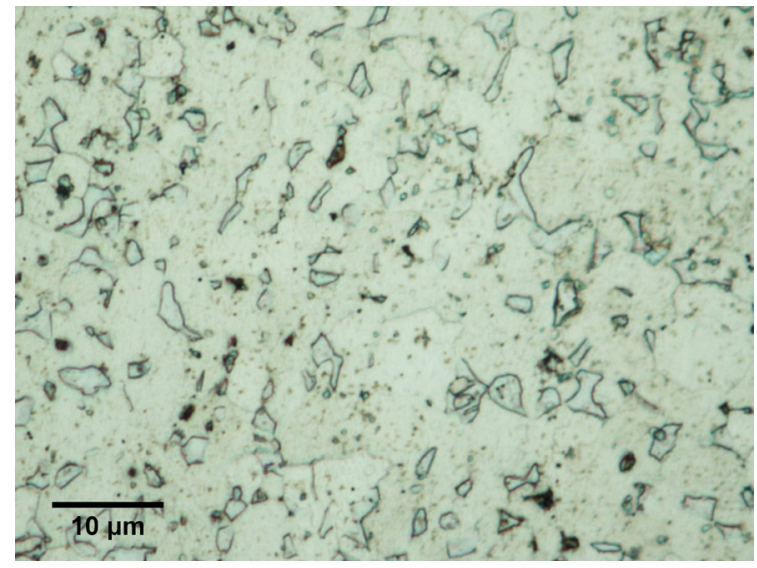

b)

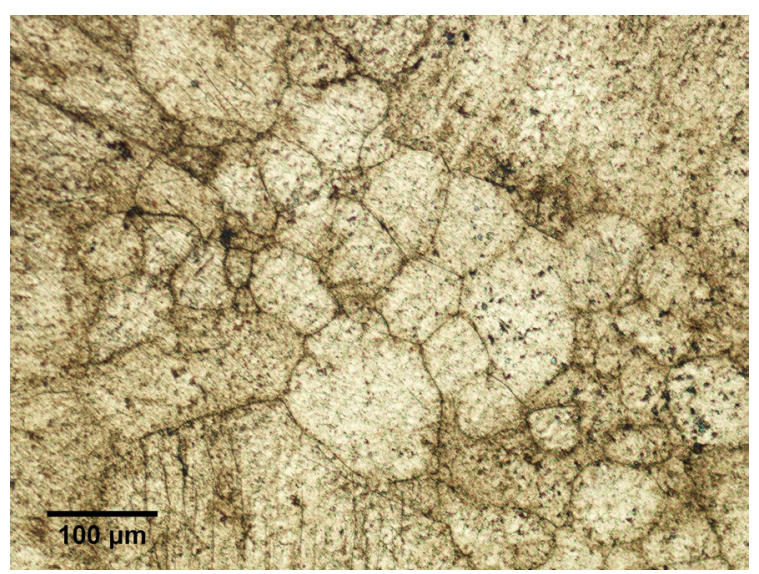

Fig. 1. Microstructure of titanium alloy: a) Ti-6Al-4V; b) Ti-10Mo-4Zr. Etching in Kroll's solution ( $\mathrm{HF}-\mathrm{HNO}_{3}-\mathrm{H}_{2} \mathrm{O}$ )

\subsection{Open-circuit potential}

The electrochemical tests confirmed that a high concentration of fluoride ions in a MAS promotes a significant deterioration of the passive layer formed at the surface of the Ti alloys. 
Figure 2 shows that the open-circuit potential measured for both Ti alloys in a MAS is much lower in a solution containing fluoride ions. Moreover, the OCP values decrease when the concentration of NaF increases in an MAS. The open-circuit potential measured for both Ti alloys quickly attains a stable value in the MAS solution (Fig. 2). The potential values obtained after about 80,000 s (22 h) are around $-7 \mathrm{mV}$ for Ti-6Al-4V (Fig. 2a - dotted black line) and about $-37 \mathrm{mV}$ for $\mathrm{Ti}-10 \mathrm{Mo}-4 \mathrm{Zr}$ vs. $\mathrm{Ag} / \mathrm{AgCl}$ (Fig. $2 \mathrm{~b}$ - dotted black line), respectively. However, the value of the OCP measured for both Ti alloys in the MAS with NaF always obtained lower values than in an MAS. The potential values at the beginning of the measurement for the Ti-6Al-4V alloy assume lower values (from -800 to $-590 \mathrm{mV}$ vs. $\mathrm{Ag} / \mathrm{AgCl}$ ) as compared to the Ti-10Mo-4Zr alloy (from -500 to $-300 \mathrm{mV}$ vs. $\mathrm{Ag} / \mathrm{AgCl}$ ) and slightly increase over time. For the Ti-10Mo-4Zr alloy, the values of potential decrease, reaching a potential value of around -390 to $-520 \mathrm{mV}$ vs. $\mathrm{Ag} / \mathrm{AgCl}$ (which is similar for both $\mathrm{NaF}$ contents).

a)

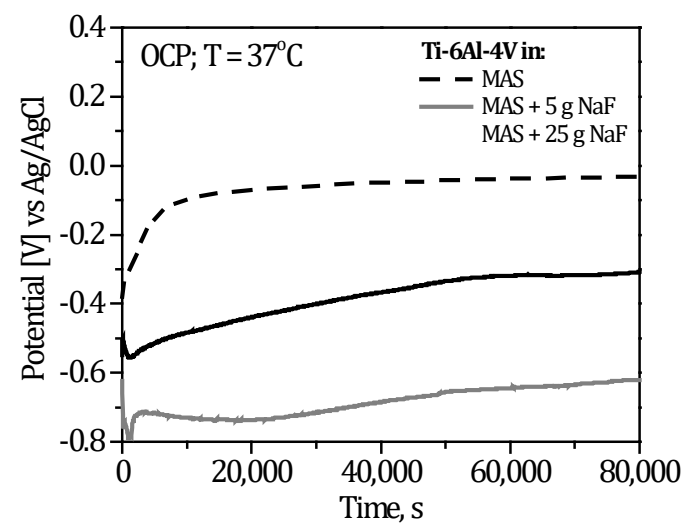

b)

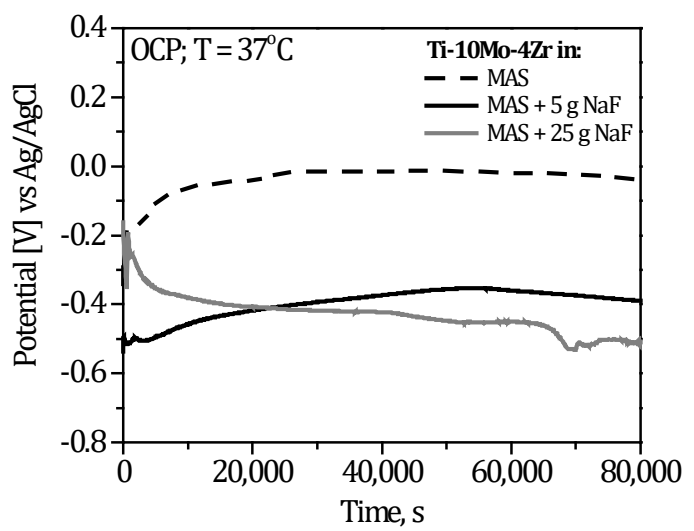

Fig. 2. Open-circuit potential of (a) Ti-6Al-4V and (b) Ti-10Mo-4Zr alloys in artificial saliva solution (MAS) and MAS with $\mathrm{NaF}$

\subsection{Linear sweep voltamperometry}

In the next stage, linear sweep voltamperometry measurements were performed for the Ti-6Al-4V and Ti-10Mo-4Zr alloys in MAS and MAS-NaF solutions. The polarization curves obtained for both Ti alloys are presented in (Fig. 3). The current density in the anodic branch measured for both Ti alloys is significantly higher in the MAS solution containing sodium fluoride. Significant increases of the current density in the anodic branch is observed for the Ti-10Mo-4Zr alloy in the MAS solution containing $25 \mathrm{~g} \mathrm{NaF}$ (Fig. 3b).

Such a large difference in the current density registered in the anodic branch was not observed for the Ti-6Al-4V alloy in the MAS and MAS containing different concentrations of $\mathrm{NaF}$. The LSV curves revealed that the current density in the anodic domain depends on the type of alloy and concentration of the fluoride ions. In Table 3, the current density values measured for both Ti alloys at an anodic potential of $0.5 \mathrm{~V}$ vs. $\mathrm{Ag} / \mathrm{AgCl}$ are presented. Generally, the mono-phase Ti-10Mo-4Zr alloy exhibits a more active behavior in the anodic domain than the Ti-6Al-4V. Moreover, it can be noticed that a higher concentration of $\mathrm{NaF}$ in the MAS solution affects the value of the equilibrium potential for both $\mathrm{Ti}$ alloys. A higher concentration of $\mathrm{NaF}$ in the MAS solution shifts the equilibrium potential to a more negative potential (Fig. 3).

a)

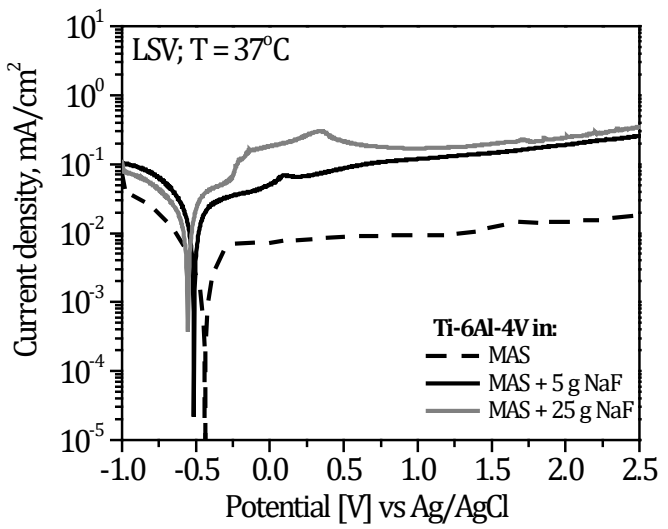

b)

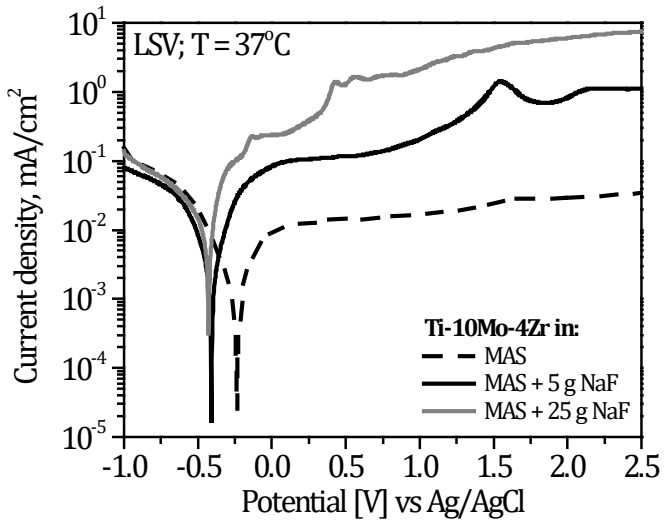

Fig. 3. Linear sweep voltamperometry of (a) Ti-6Al-4V and (b) Ti-10Mo-4Zr alloys in artificial saliva solution (MAS) and MAS with $\mathrm{NaF}$

Table 3

Anodic current density values measured for Ti-6Al-4V and Ti-10Mo-4Zr alloys, respectively, at $0.5 \mathrm{~V}$ vs. $\mathrm{Ag} / \mathrm{AgCl}$ in MAS and MAS with NaF solutions

\begin{tabular}{lccc}
\hline \multirow{2}{*}{$\begin{array}{c}\text { Alloy } \\
\text { Solution }\end{array}$} & \multicolumn{3}{c}{$\begin{array}{c}\text { Current density, } \\
\mathbf{m A} / \mathbf{c m}^{2}\end{array}$} \\
\cline { 2 - 4 } & MAS & MAS + 5 g NaF & MAS + 25 g NaF \\
\hline Ti-6Al-4V & $8.8 \cdot 10^{-3}$ & $85.5 \cdot 10^{-3}$ & $202.3 \cdot 10^{-3}$ \\
\hline Ti-10Mo-4Zr & $8.0 \cdot 10^{-3}$ & $114.9 \cdot 10^{-3}$ & $986.5 \cdot 10^{-3}$ \\
\hline
\end{tabular}


According to the literature data, the deterioration of the corrosive properties in the case of titanium and its alloys immersed in a solution of artificial saliva with the addition of fluorides largely corresponds to the Ti-F complex formed on the surface of the alloys in the form of compounds $\mathrm{Na}_{2} \mathrm{TiF}_{6}, \mathrm{TiOF}_{2}, \mathrm{TiF}_{4}$, and $\mathrm{TiF}_{3}[24,25]$. Despite the low solubility of $\mathrm{NaF}$ in water, a reaction occurs (Eqs. (1) and (2)). The rate of the reaction taking place is not known; however, the resulting ions accelerate the dissolution of the passive layer of the alloys. If the solution is acidic (in our work, the MAS had a pH level of 6.4), the reaction mechanisms on the surface of titanium alloys can look like those of a solution of hydrofluoric acid HF [26]. The processes occurring on the surface of the titanium alloys in the presence of $\mathrm{F}^{-}$ions are also present in the following reactions with hydrofluoric acid (Eqs. (3)-(5)), which is mainly attributed to the destruction of the surface $[24,27,28]$ :

$$
\begin{gathered}
\mathrm{NaF}+\mathrm{H}_{2} \mathrm{O}=\mathrm{Na}^{+}+\mathrm{OH}^{-}+\mathrm{HF} \\
2 \mathrm{HF}=\mathrm{H}_{2} \mathrm{~F}^{+}+\mathrm{F}^{-} \\
\mathrm{TiO}_{2}+2 \mathrm{HF}=\mathrm{TiOF}_{2}+\mathrm{H}_{2} \mathrm{O} \\
\mathrm{TiO}_{2}+4 \mathrm{HF}=\mathrm{TiF}_{4}+2 \mathrm{H}_{2} \mathrm{O} \\
\mathrm{Ti}_{2} \mathrm{O}_{3}+6 \mathrm{HF}=2 \mathrm{TiF}_{3}+3 \mathrm{H}_{2} \mathrm{O}
\end{gathered}
$$

Figure 4 presents the behavior of titanium in solutions with the addition of $\mathrm{NaF}$ at various $\mathrm{pH}$ levels. When we deal with a solution with a slightly acidic $\mathrm{pH}$, the passive layer is slowly dissolved (which is schematically indicated in Figure 4a). This is explained by the low OCP values and high anodic currents in the MAS solution with the addition of $\mathrm{NaF}$. When the solution has a neutral $\mathrm{pH}$, the presence of fluoride ions has no significant effect on the dissolution of the passive layer [29]. a)

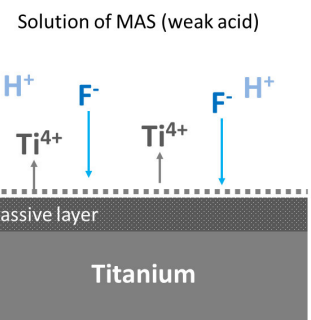

b) Solution of MAS (neutral)

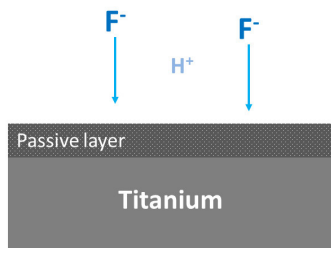

Fig. 4. Scheme of influence of $\mathrm{F}^{-}$ions on surface layer of titanium and its alloys depending on $\mathrm{pH}$ level of solution: (a) solution with slightly acidic pH MAS and (b) neutral solution of MAS [26]

The effect on the instability of the passive layer of titanium alloys in contact with $\mathrm{F}^{-}$ions depends on the chemical composition of the passive film. Fluoride is highly reactive for titanium alloy with molybdenum [30]. The increasing intensity of the dissolution of the Ti-10Mo-4Zr alloy at a potential of $>0.5 \mathrm{~V}$ vs. $\mathrm{Ag} / \mathrm{AgCl}$ (Fig. $3 \mathrm{~b}$ ) is determined by the formation of fluoride compounds with molybdenum on the surface. Primary molybdenum compounds $\mathrm{MoF}_{6}$ and $\mathrm{MoO}_{3}$ oxidize to form $\mathrm{MoOF}_{4}$, which has much less resistance to corrosion [31]. Continuous exposure to fluorine reduces the protective properties of the passive layer, which corresponds to the reduced stationary potential.

The Ti-6Al-4V alloy contains vanadium; its passive layer is in the form of vanadium (III) oxide. In contact with hydrofluoric acid, it forms vanadium (III) fluoride according to Reaction (6):

$$
\mathrm{V}_{2} \mathrm{O}_{3}+6 \mathrm{HF} \rightarrow 2 \mathrm{VF}_{3}+3 \mathrm{H}_{2} \mathrm{O}
$$

\subsection{Electrochemical behavior in anodic domain}

To confirm the obtained results and characterize the structures of the surface layers of the titanium alloys, an EIS measurement was carried out (Fig. 5) for each titanium alloy at a potential of $0.5 \mathrm{~V}$ vs. $\mathrm{Ag} / \mathrm{AgCl}$ in MAS with the addition of sodium fluoride after previous chronoamperometry at a potential of $0.5 \mathrm{~V}$ vs. $\mathrm{Ag} / \mathrm{AgCl}$ for $1200 \mathrm{~s}$.

a)

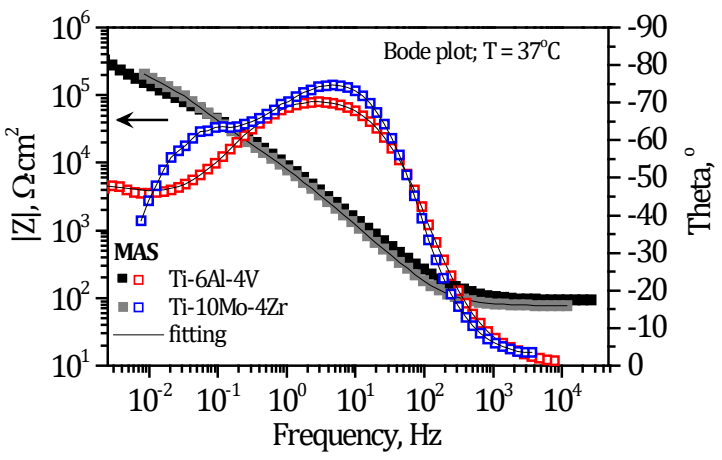

b)

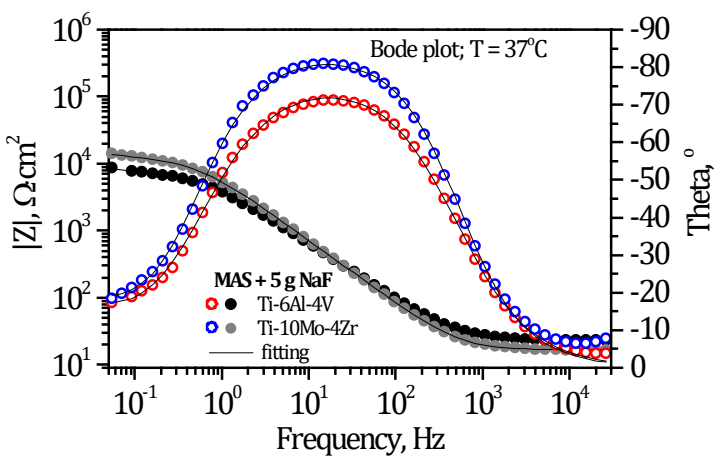

c)

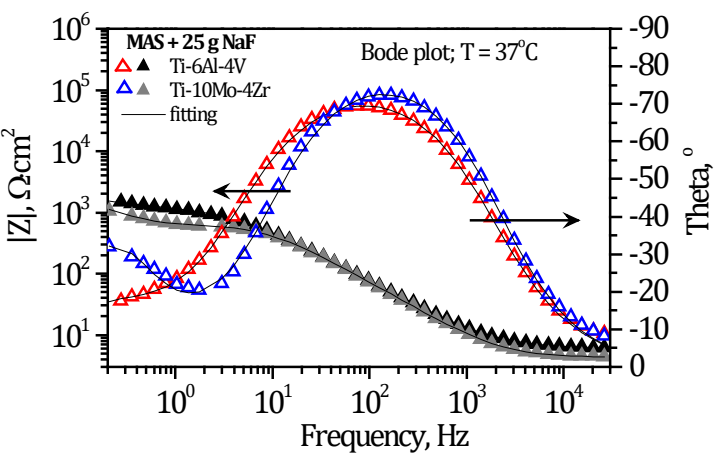

Fig. 5. Electrochemical impedance diagrams: Bode plots obtained on Ti-6Al-4V and Ti-10Mo-4Zr alloys in (a) MAS, (b) MAS + 5 g NaF, and (c) $\mathrm{MAS}+25 \mathrm{~g} \mathrm{NaF}$ at $37^{\circ} \mathrm{C}$ at $0.5 \mathrm{~V}$ vs. $\mathrm{Ag} / \mathrm{AgCl}$. Potential was applied for $1200 \mathrm{~s}$ before EIS measurements 
It can be clearly seen that, at a content of $25 \mathrm{~g} \mathrm{NaF}$ (Fig. 5c), the resistance of the passive layer of the titanium alloys is much lower. It shows this on reducing the corrosion resistance in this environment. Compared to the solution of artificial saliva without $\mathrm{NaF}$, the resistance is 100 times greater (Fig. 5a), and for a content of $5 \mathrm{~g} \mathrm{NaF}$, it is 10 times higher (Fig. 5b).

Simulations of the EIS results obtained (Tab. 4) showed that the passive layer formed on the surface of both titanium alloys in the MAS solution with the addition of $\mathrm{NaF}$ is formed in two stages. The adapted electric equivalent circuit contains two time constants that are attributed to the existence of a passive layer and the build-up of corrosive products over the course of time (in this case, compounds with fluorine). In order to characterize the passive layer, a constant-phase CPE element was introduced into the circuit, which is characterized by two constants ( $\mathrm{T}$ and $\mathrm{P}$ ). Comparing the values obtained for CPE1-P (exponent $\mathrm{P}$ for $\mathrm{CPE}$ ) in each of the used solutions value $>0.83$, which indicates the capacitive properties of the passive layer of each alloy. Nevertheless, for the Ti-6Al-4V alloy, the CPE1-P values are lower than for the Ti-10Mo-4Zr alloy (above 0.9).

The obtained CPE2-P values for both titanium alloys differ more depending on the electrolyte used. For $5 \mathrm{~g} \mathrm{NaF}$ in solution, CPE2-P takes values between $0.62-0.66$, which suggests that there is an addition of ion diffusion (Fig. 6b) through the corrosion product layer (Fig. 5b). In the Bode plot, it is noteworthy that the frequency characteristics are of a similar shape at a wide range of frequencies. The difference in the value of the phase shift angle is visible for both alloys at high frequencies. A much higher phase angle occurs for the Ti-10Mo-4Zr alloy (approximately $-81^{\circ}$ ). This means it has a higher corrosion resistance as compared to the Ti-6Al-4V alloy (for which the phase shift angle is around $-71^{\circ}$ ).

For a solution containing $25 \mathrm{~g} \mathrm{NaF}$, the corrosion behavior of the passive layer is not the same for the titanium alloys (Fig. 5c). Mainly due to the use of an electric equivalent circuit comprising a resistance of R3 (Fig. 6a) the Ti-10Mo-4Zr alloy is composed of a double layer with better capacitive properties (a CPE2-P close to 1 ) and a higher R3 value than R2 $\left(\sim 1300 \Omega \cdot \mathrm{cm}^{2}\right)$. On the other hand, the Ti-6Al-4V alloy is characterized by a lower CPE2-P value, which may ambiguously indicate the structure of the passive layer: an intermediate state between the capacitive properties of the layer and the occurring diffusion processes. In each case, the resistance of the electrolyte (R1) and resistance of R2 decreases as the NaF content in the MAS increases.

a)

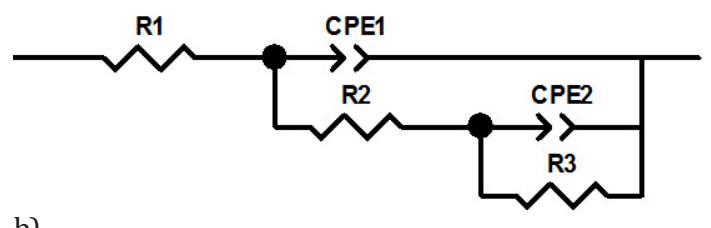

b)

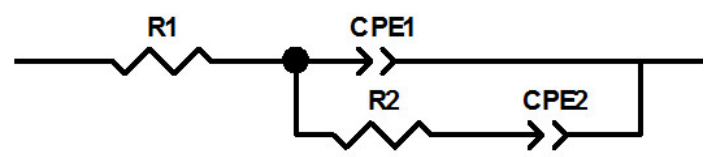

Fig. 6. Electric equivalent circuit from simulation for Ti-6Al-4V and Ti-10Mo-4Zr titanium alloys in MAS with (a) $5 \mathrm{~g} \mathrm{NaF}$ and (b) $25 \mathrm{~g} \mathrm{NaF}$

\section{CONCLUSIONS}

The sodium fluoride concentration in a saliva solution has a significant influence on the electrochemical behavior of titanium alloys. Proportionally to the increase in the concentration of fluoride ions in the saliva solution, the corrosion resistance of titanium alloys decreases. At low concentrations of fluoride ions, the diffusion phenomena occur in the layer of corrosive products. The differences in the behavior of titanium alloys are noticeable at higher concentrations of fluoride ions, where the Ti-10Mo-4Zr alloy has a typical two-layer structure, having capacitive properties with a lower resistance in the outer layer. The Ti-6Al-4V alloy forms a layer that ambiguously corresponds to the capacitive layer as well as the phenomenon of diffusion through the corrosion products.

Table 4

Values of fitted parameters of equivalent circuit as function of applied potential $0.5 \mathrm{~V}$ vs. Ag/AgCl of Ti-6Al-4V and Ti-10Mo- $4 \mathrm{Zr}$ alloys in MAS with different contents of $\mathrm{NaF}$

\begin{tabular}{|c|c|c|c|c|c|c|c|c|}
\hline Solution & Sample & $\begin{array}{c}\mathbf{R} 1, \\
\Omega \cdot \mathbf{c m}^{2}\end{array}$ & $\begin{array}{c}\mathbf{R 2}, \\
\Omega \cdot \mathbf{c m}^{2}\end{array}$ & $\begin{array}{c}\text { CPE1-T } \\
\times 10^{-5} \\
\Omega \cdot \mathbf{c m}^{-2} \mathbf{S}^{\varphi}\end{array}$ & CPE1-P & $\begin{array}{c}\mathbf{R 3}, \\
\mathbf{\Omega} \cdot \mathbf{c m}^{2}\end{array}$ & $\begin{array}{c}\text { CPE2-T } \\
\times 10^{-4}, \\
\Omega \cdot \mathbf{c m}^{-2} \mathbf{S}^{\varphi}\end{array}$ & CPE2-P \\
\hline \multirow{2}{*}{ MAS } & Ti-6Al-4V & 94.9 & 39,800 & 2.1 & 0.83 & - & 0.21 & 0.53 \\
\hline & Ti-10Mo-4Zr & 77.4 & 23,900 & 2 & 0.9 & 334,400 & 0.19 & 0.75 \\
\hline \multirow{2}{*}{$\begin{array}{c}\text { MAS } \\
+5 \mathrm{~g} \mathrm{NaF}\end{array}$} & Ti-6Al-4V & 22.5 & 7833 & 4.3 & 0.86 & - & 11.6 & 0.66 \\
\hline & Ti-10Mo-4Zr & 16.6 & 12,085 & 2.8 & 0.94 & - & 5.6 & 0.62 \\
\hline \multirow{2}{*}{$\begin{array}{c}\text { MAS } \\
+25 \mathrm{~g} \mathrm{NaF}\end{array}$} & Ti-6Al-4V & 5.9 & 1224 & 5.3 & 0.86 & 1011 & 12.1 & 0.79 \\
\hline & Ti-10Mo-4Zr & 4.3 & 658.4 & 4.1 & 0.91 & 1280 & 9.8 & 0.98 \\
\hline
\end{tabular}




\section{Acknowledgements}

This work was supported by statutory project no. 11.11.170.318, task 12 .

\section{REFERENCES}

[1] Alves V.A., Reis R.Q., Santos I.C.B., Souza D.G., de F. Gonçalves T., Pereira-da-Silva M.A., Rossi A.\& da Silva L.A. (2009). In situ impedance spectroscopy study of the electrochemical corrosion of $\mathrm{Ti}$ and $\mathrm{Ti}-6 \mathrm{Al}-4 \mathrm{~V}$ in simulated body fluid at $25^{\circ} \mathrm{C}$ and $37^{\circ}$ C. Corrosion Science, 51(10), 2473-2482. Doi:10.1016/ j.corsci.2009.06.035

[2] Kim E.-J., Jeong Y.-H., Choe H.-C. \& Brantley W. (2012). Surface phenomena of HA/TiN coatings on the nanotubular-structured beta Ti-29Nb-5Zr alloy for biomaterials. Applied Surface Science, 258(6), 2083-2087. Doi:10.1016/ j.apsusc.2011.04.051.

[3] Hsu R. W.-W., Yang C.-C., Huang C.-A. \& Chen Y.-S. (2004). Investigation on the corrosion behavior of Ti-6Al-4V implant alloy by electrochemical techniques. Materials Chemistry and Physics, 86(2-3), 269-278. Doi:10.1016/ j.matchemphys.2004.02.025.

[4] Sivakumar B., Kumar S. \& Sankara Narayanan T.S. (2011). Fretting corrosion behaviour of Ti-6Al-4V alloy in artificial saliva containing varying concentrations of fluoride ions. Wear, 270(3-4), 317-324. Doi:10.1016/j.wear.2010.09.008.

[5] Biesiekierski A., Ping D.H., Yamabe-Mitarai Y. \& Wen C. (2014). Impact of ruthenium on microstructure and corrosion behavior of $\beta$-type Ti-Nb-Ru alloys for biomedical applications. Materials and Design, 59, 303-309. Doi:10.1016/ j.matdes.2014.02.058.

[6] Cui W.F., Jin L. \& Zhou L. (2013). Surface characteristics and electrochemical corrosion behavior of a pre-anodized microarc oxidation coating on titanium alloy. Materials Science and Engineering: C, 33(7), 3775-3779. Doi:10.1016/ j.msec.2013.05.011.

[7] Milošev I., Žerjav G., Calderon Moreno J.M. \& Popa M. (2013). Electrochemical properties, chemical composition and thickness of passive film formed on novel Ti-20Nb-10Zr-5Ta alloy. Electrochimica Acta, 99, 176-189. Doi:10.1016/ j.electacta.2013.03.086.

[8] Mohan L. \& Anandan C. (2013). Wear and corrosion behavior of oxygen implanted biomedical titanium alloy Ti-13Nb-13Zr. Applied Surface Science, 282(1), 281-290. Doi:10.1016/j.apsusc.2013.05.120.

[9] Krawiec H., Vignal V., Loch J. \& Erazmus-Vignal P. (2015). Influence of plastic deformation on the microstructure and corrosion behaviour of Ti-10Mo-4Zr and Ti-6Al-4V alloys in the Ringer's solution at $37^{\circ} \mathrm{C}$. Corrosion Science, 96, 160-170. Doi:10.1016/j.corsci.2015.04.006.

[10] Tsutsumi Y., Niinomi M., Nakai M., Tsutsumi H., Doi H., Nomura N. \& Hanawa T. (2012). Micro-arc oxidation treatment to improve the hard-tissue compatibility of Ti-29Nb-13Ta-4.6Zr alloy. Applied Surface Science, 262, 34-38. Doi:10.1016/j.apsusc.2012.01.024.

[11] Diomidis N., Mischler S., More N.S. \& Roy M. (2012). Tribo-electrochemical characterization of metallic biomaterials for total joint replacement. Acta Biomaterialia, 8(2), 852-859. Doi:10.1016/j.actbio.2011.09.034.

[12] Zhao C., Zhang X. \& Cao P. (2011). Mechanical and electrochemical characterization of Ti-12Mo-5Zr alloy for biomedical application. Journal of Alloys and Compounds, 509(32), 8235-8238. Doi:10.1016/j.jallcom.2011.05.090.

[13] Wang Z., Huang W. \& Ma Y. (2014). Micro-scale abrasive wear behavior of medical implant material Ti-25Nb-3Mo-3Zr-2Sn alloy on various friction pairs. Materials Science and Engineering $C$, 42, 211-218. Doi:10.1016/j.msec.2014.05.039.

[14] González M., Peña J., Gil F.J. \& Manero J.M. (2014). Low modulus Ti-Nb-Hf alloy for biomedical applications. Materials Science and Engineering C, 42, 691-695. Doi:10.1016/ j.msec.2014.06.010.
[15] Diomidis N., Mischler S., More N.S., Roy M. \& Paul S.N. (2011). Fretting-corrosion behavior of $\beta$ titanium alloys in simulated synovial fluid. Wear, 271(7-8), 1093-1102.

[16] Castro M., Ponces M.J., Lopes J.D. \& Pollmann M.C.F. (2015). Orthodontic wires and its corrosion - The specific case of stainless steel and beta-titanium. Journal of Dental Sciences, 10(1), 1-7. Doi:10.1016/j.jds.2014.07.002.

[17] Loch J., Krawiec H., Łukaszczyk A. \& Augustyn-Pieniążek J. (2016). Corrosion resistance of titanium alloys in the artificial saliva solution. Journal of Achievements in Materials and Manufacturing Engineering, 74(1), 29-36.

[18] Sampaio M., Buciumeanu M., Henriques B., Silva F.S., Souza J.C.M. \& Gomes J.R. (2015). Tribocorrosion behavior of veneering biomedical PEEK to Ti6Al4V structures. Journal of the Mechanical Behavior of Biomedical Materials, 54, 123-130. Doi:10.1016/j.jmbbm.2015.09.010.

[19] Mareci D., Chelariu R., Gordin D.M., Ungureanu G. \& Gloriant T. (2009). Comparative corrosion study of Ti-Ta alloys for dental applications. Acta Biomaterialia, 5(9), 3625-3639. Doi:10.1016/j.actbio.2009.05.037.

[20] Schiff N., Grosgogeat B., Lissac M. \& Dalard F. (2002). Influence of fluoride content and $\mathrm{pH}$ on the corrosion resistance of titanium and its alloys. Biomaterials, 23(9), 1995-2002. Retrieved from http://www.ncbi.nlm.nih.gov/ pubmed/11996041 (accessed 25.06.2018).

[21] Souza J.C.M., Ponthiaux P., Henriques M., Oliveira R., Teughels W., Celis J.-P. \& Rocha L.A. (2013). Corrosion behaviour of titanium in the presence of Streptococcus mutans. Journal of dentistry, 41(6), 528-34. Doi:10.1016/j.jdent. 2013.03.008.

[22] PN-EN ISO 10993-15. (2005). Biologiczna ocena wyrobów medycznych - Cz. 15; Identyfikacja i oznaczanie ilościowe produktów degradacji metali i stopów.

[23] Vieira A.C., Ribeiro A.R., Rocha L. \& Celis J.P. (2006). Influence of $\mathrm{pH}$ and corrosion inhibitors on the tribocorrosion of titanium in artificial saliva. Wear, 261(9), 994-1001. Doi:10.1016/j.wear.2006.03.031.

[24] Souza J.C.M., Barbosa S.L., Ariza E., Celis J.-P. \& Rocha L. (2012). Simultaneous degradation by corrosion and wear of titanium in artificial saliva containing fluorides. Wear, 292-293, 82-88. Doi:10.1016/j.wear.2012.05.030.

[25] Huang H.-H. \& Lee T.-H. (2005). Electrochemical impedance spectroscopy study of Ti-6Al-4V alloy in artificial saliva with fluoride and/or bovine albumin. Dental Materials, 21(8), 749-755. Doi:10.1016/j.dental.2005.01.009.

[26] Sakairi M., Kinjyo M. \& Kikuchi T. (2011). Repassivation behavior of titanium in artificial saliva investigated with a photon rupture method. Electrochimica Acta, 56(4), 1786-1791. Doi:10.1016/j.electacta.2010.08.090.

[27] Loch J., Krawiec H. \& Łukaszczyk A. (2015). Wpływ fluorków i kwasu mlekowego na odporność korozyjną stopów tytanu w symulowanym roztworze sztucznej śliny. Archives of Foundry Engineering, 1(4), 87-90.

[28] Takemoto S., Hattori M., Yoshinari M., Kawada E. \& Oda Y (2005). Corrosion behavior and surface characterization of titanium in solution containing fluoride and albumin. Biomaterials, 26(8), 829-837. Doi:10.1016/j.biomaterials. 2004.03.025.

[29] Golvano I., Garcia I., Conde A., Tato W. \& Aginagalde A. (2015). Influence of fluoride content and $\mathrm{pH}$ on corrosion and tribocorrosion behaviour of Ti13Nb13Zr alloy in oral environment. Journal of the Mechanical Behavior of Biomedical Materials, 49, 186-196. Doi:10.1016/j.jmbbm. 2015.05.008.

[30] Dąbrowska E., Balunowska M. \& Letko R. (2001). Zagrożenia wynikające z nadmiernej podaży fluoru. Nowa Stomatologia, 4, 22-27.

[31] Nakai H., Morita H., Tomasello P. \& Nakatsuji H. (1998). Electronic structures of MoF6 and MoOF4 in the ground and excited states: A SAC-CI and frozen-orbital-analysis study. Journal of Physical Chemistry A, 102(11), 2033-2043. Doi:10.1021/jp973052s. 